\title{
INVESTIGATIONS IN FEEDING DEVICE OF GRAIN CRUSHER
}

\author{
Peter Savinyh $^{1}$, Vladimir Kazakov ${ }^{1}$, Alexander Moshonkin ${ }^{2}$, Semjons Ivanovs ${ }^{3}$ \\ ${ }^{1}$ North-East Agricultural Research Institute, Russia; ${ }^{2}$ Vyatka State Agricultural Academy, Russia; \\ ${ }^{3}$ Latvia University of Life Sciences and Technologies, Latvia \\ semjons@apollo.lv
}

\begin{abstract}
Design-and-technological and structural schemes of the forage grain crusher have been developed with a feeding device consisting of a drum with straight blades mounted in a housing under the bunker above an adjustable window, and a supply channel for directing the grain falling from the blades of the feeding drum to the crushing area by the working blades of the crusher. With an aim to optimise the technological process of crushing grain preliminary theoretical and experimental investigations of the design-and-technological parameters of the feeding device of the crusher have been carried out. It has been theoretically established that the speed and directions of feeding the grain to the crushing area affect the efficiency of the technological process of crushing. Experimental studies show that a change in the value of the peripheral speed (linear velocity of the outer edges) of the blades of the feeding drum significantly changes the main technical and economic indicators of the technological process of producing crushed grain forage - the efficiency (throughput) of the machine and the specific energy consumption. It was found that entry of the grain into the crushing area from the feeder at a speed equal to or close to the peripheral speed of the drums for conditioning results in an increase in the efficiency of the crusher by 2.2 times and reduces the energy intensity of the process by 1.6 times. In addition, the best indicators for the production of crushed forage are observed within the range of speeds for the introduction of grain into the crushing area $8 \ldots 9 \mathrm{~m} \mathrm{~s}^{-1}$, which practically corresponds to the peripheral speed of the blades of the feeding drum and the rollers for crushing. The investigations allow developing a grain crusher at a design stage with a high-quality product, minimum energy intensity of the working process and maximum possible throughput.
\end{abstract}

Keywords: grain, crushing, efficiency, costs, feeding, device.

\section{Introduction}

In many countries of the world forage grain is the most important source of fodder in animal husbandry. It has been established by studying the feeding process of grain to ruminants and the impact upon their productivity depending on the kind and the degree of crushing (flattening, crimping) this type of concentrated feed that whole grain is absorbed by animals much worse than, for example, the crushed one [1-3]. This is because the outer shell of the grain consists of a fibre that prevents access of enzymes of the digestive juice to the nutrients of the grain. The crushed grain also has disadvantages, since it tends to settle in the rumen of the stomach and quickly passes through the forestomachs of the ruminants, which leads to decreased digestibility of the nutrients in the grain, in particular, to the conversion of biologically imperfect albumen into biologically complete, to the conversion of carbohydrates into volatile fatty acids, and so on.

One kind of forage, most compatible with biochemical processes occurring in the rumen of a ruminant animal is the flattened grain fodder, produced by passing the grain through a gap formed by rollers rotating towards each other [4;5].

When flattening, the outer shell (the fibre) of the grain is broken, which prevents access of enzymes to the nutrients. When this grain is fed to the animal, the contact area between the nutrients of the grain and the enzyme system of the gastrointestinal tract of the animal increases several times. In addition, the flattened grain has an optimal size for its uniform distribution over the entire rumen of the cow, which leads to better consumption of carbohydrates and proteins by microorganisms. In this case the imperfect albumen is easily transformed by the microorganisms into a biologically complete one (by its composition it is mostly similar to the amino acid content of milk), which, in turn, is fodder for the animal.

A large number of studies have been devoted to the investigation of machines for grain flattening [6]. However, the problem how to improve the technical means in order to raise their efficiency and reduce their energy intensity remains topical. The purpose of this work is to investigate a new feeding device of a grain crusher that makes it possible to improve the performance and energy intensity indicators. 


\section{Materials and methods}

Analysis of the previous studies [6] shows that: the greatest throughput capability of grain crushing is observed at the shortest time of passage of grain through the crushing zone; this condition is fulfilled, if the input speed of the weevil into the working zone of crushing is equal to the linear velocity on the working surfaces of the rollers for crushing. The fulfillment of this condition is ensured by the installation of the feeding device.

On the basis of the conducted analysis of the technology level of the issue under consideration [68] and taking into account the operation experience of the PZ-1 grain crusher, a design-andtechnological flow scheme of the PZ-1M grain crusher (Fig. 1) with a feeding device (Fig. 2) for feeding grain into the working area (the inter-roll gap) of the crusher [7-9] has been developed.

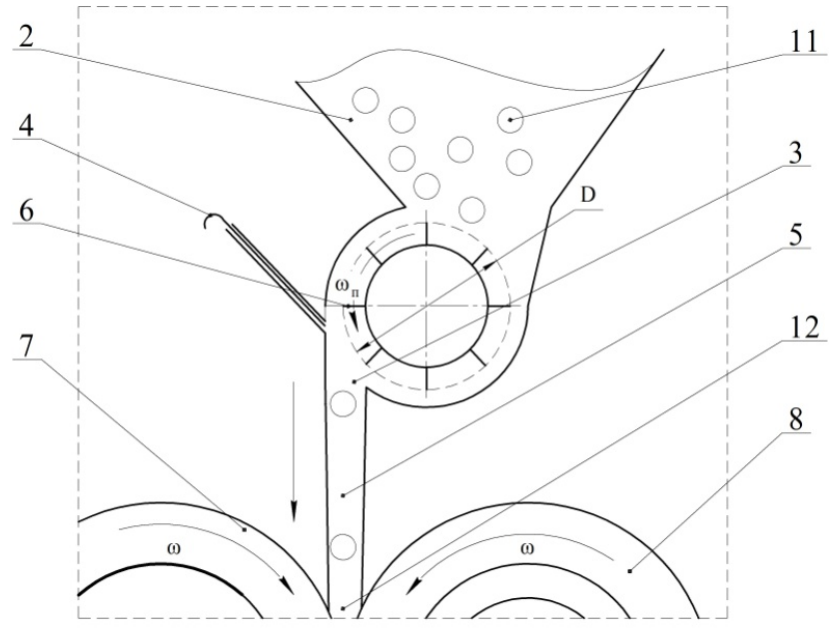

Fig. 1. Scheme of feeding device of PZ-1M forage grain crusher: 1 - frame; 2 - feeding hopper; 3 - window; 4 - flap; 5 - grain feeding channel; 6 - feeding roll ; 7, 8 - rollers for flattening (basic);

9 - electric motor; 10 -vee belt transmission; 11 - grain for flattening; 12 - inter-roll gap

a)

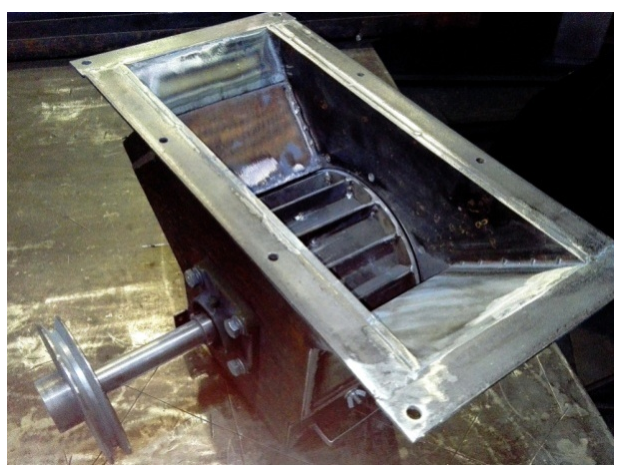

b)

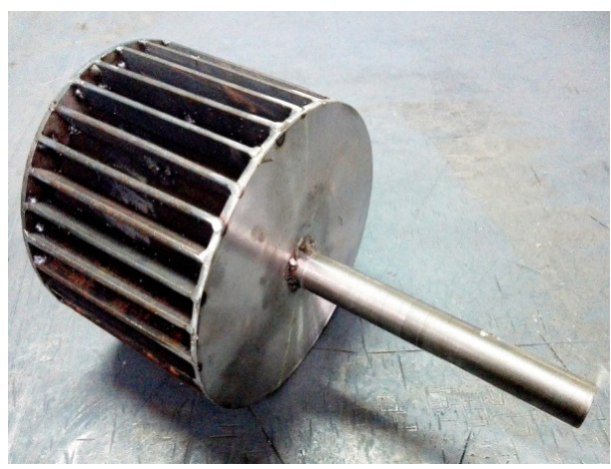

Fig. 2. General view of experimental sample of feeding device (a) and its working tool - feeding roll (b)

A general view of the grain crusher PZ-1M is shown in Fig. 3. The operations of the technological process for production of grain forage by the new crusher according to [9] are conventionally divided into two groups: mechanical movements (transportation) and transformations. The first group includes delivery of the forage grain to the crusher (part of the path of movement of the grain material $O B$ ), removal of the produced forage from the working area of the crusher to the outside (section $C D$ ); transformations include flattening of the forage grain (section BC). The movements and transformations organise a continuous technological process of producing flattened fodder; their optimal combination determines the flow efficiency of the technological process of any machine. The grain crusher can be used for flattening grain of waxy ripeness, forage grain of full ripeness with a moisture content of more than $20 \%$, for flattening dry forage grain. It works as follows. The grain material to be crushed (the grain) 11 (Fig. 1) is loaded into the feeding hopper 2. When the window is opened with the adjusting flap 4, which allows adjustment of the throughput rate of the crusher, the 
grain material (the grain for flattening) 11 , located in the feeding hopper 2 , is captured by the grooves of the feeding roll 6 and delivered through the window 3 and the feeding channel 5, and through it into the inter-roll gap 12 of the rollers 7 and 8, where it is captured by the rollers; and the flattening (crushing) takes place.

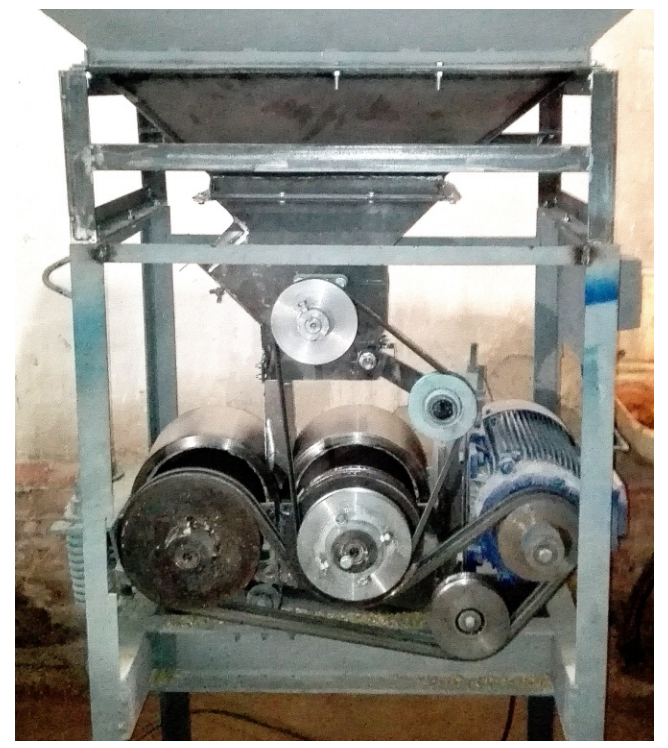

Fig. 3. General view of grain crusher PZ-1M

Then it is removed from the inter-roll gap 12 and, as a finished product - flattened forage grain it is sent for storage or directly for feeding. Installation of the feeding roll 6 in the feeding hopper 2 of the crusher above the height-adjustable window 3 loosens the grain 11 entering the hopper for flattening, which eliminates its hanging up in the hopper 2, thereby ensuring the continuity and uniformity of feeding the grain 11 , and, consequently, continuity of the entire process of crushing the grain, thus raising the efficiency of the crusher. In addition, the grain enters the crushing area from the roll 6 through the channel 5.

At the initial stage a preliminary study of the crushing operation by means of a crusher with a feeding device was carried out, the results of which revealed factors that make the greatest impact upon its efficiency (the crushing efficiency $\mathrm{Q}, \mathrm{t} \mathrm{h}^{-1}$, and the specific energy consumption $\mathrm{E}, \mathrm{kW} \cdot \mathrm{h} \cdot \mathrm{t}$ $\left.{ }^{1}\right)$ : the rotation frequency of the roll of the feeding device $n$, the number of blades of the roll $z$, the diameter of the roll of the feeding device $D$, the installation height of the feeding roll relative to the working area of crushing $h$, the inclination angle of the blades of the roller $\alpha$. Taking into account the planning theory of a multifactor experiment [10-12], to study the combined influence of the design and technological factors of the feeding device upon the performance indicators of the crusher, a full factorial experiment of type $2^{5-1}$ was implemented. The variation levels of the factors, the matrix (plan) are shown in Table 1.

Table 1

Factors and their variation levels

\begin{tabular}{|c|c|c|c|c|c|}
\hline \multirow{2}{*}{$\begin{array}{c}\text { Variation levels of } \\
\text { factors }\end{array}$} & $\begin{array}{c}\text { Rotation } \\
\text { frequency of } \\
\text { the shaft of the } \\
\text { feeding device } \\
n, \mathrm{~min}^{-1}\end{array}$ & $\begin{array}{c}\text { Number } \\
\text { of blades } \\
\text { on the roll } \\
z, \mathrm{pcs}\end{array}$ & $\begin{array}{c}\text { Diameter of } \\
\text { the roll of the } \\
\text { feeding device } \\
D, \mathrm{~m}\end{array}$ & $\begin{array}{c}\text { Installation } \\
\text { height of the } \\
\text { feeding } \\
\text { device } h, \mathrm{~mm}\end{array}$ & $\begin{array}{c}\text { Inclination } \\
\text { angle of the } \\
\text { blades } \alpha, \text { deg }\end{array}$ \\
\cline { 2 - 6 } & $x_{1}$ & $x_{2}$ & $x_{3}$ & $x_{4}$ & $x_{5}$ \\
\hline $\begin{array}{c}\text { The upper level } \\
(+)\end{array}$ & 900 & 32 & 0.2 & 370 & 15 \\
\hline The lower level (-) & 600 & 16 & 0.12 & 320 & 0 \\
\hline
\end{tabular}




\section{Results and discussion}

The results of the multifactor experiment against the background of the matrix of the plan are shown in Table 2.

Matrix of the plan $2^{5-1}$ and the results of experimental investigations

Table 2

\begin{tabular}{|c|c|c|c|c|c|c|c|}
\hline & \multicolumn{9}{|c|}{ Factors } & \multicolumn{2}{c|}{ Optimisation criteria } \\
\cline { 2 - 8 } No. & $\begin{array}{c}\text { Rotation } \\
\text { trequency of } \\
\text { the shaft of the } \\
\text { feeding device } \\
n, \text { min }^{-1}\end{array}$ & \begin{tabular}{c} 
Number \\
of blades \\
on the roll \\
$z$, pcs \\
\cline { 2 - 8 }
\end{tabular} & $\begin{array}{c}\text { of the roll } \\
\text { of the } \\
\text { feeding } \\
\text { device } D, \\
\mathrm{~m}\end{array}$ & $\begin{array}{c}\text { Installatio } \\
\text { height } \\
\text { of the } \\
\text { feeding } \\
\text { device } h, \\
\text { mm }\end{array}$ & $\begin{array}{c}\text { Inclinati } \\
\text { on angle } \\
\text { of the } \\
\text { blades } \\
\alpha, \text { deg }\end{array}$ & $\begin{array}{c}\text { Efficiency } \\
Q, \mathrm{t}^{-1}\end{array}$ & $\begin{array}{c}\text { Specific } \\
\text { energy } \\
\text { consump- } \\
\text { tion } E, \mathrm{~kW}\end{array}$ \\
\hline 1 & $x_{1}$ & $x_{2}$ & $x_{3}$ & $x_{4}$ & $x_{5}$ & $y_{1}$ & $y_{2}$ \\
\hline 2 & -1 & -1 & -1 & -1 & -1 & 0.892 & 4.97 \\
\hline 3 & +1 & +1 & -1 & -1 & -1 & 0.995 & 4.58 \\
\hline 4 & -1 & -1 & +1 & +1 & +1 & 1.242 & 4.1 \\
\hline 5 & +1 & -1 & +1 & -1 & -1 & 1.186 & 3.42 \\
\hline 6 & -1 & +1 & +1 & -1 & -1 & 0.984 & 4.63 \\
\hline 7 & -1 & -1 & -1 & +1 & +1 & 0.889 & 4.8 \\
\hline 8 & +1 & +1 & -1 & +1 & +1 & 0.98 & 4.44 \\
\hline 9 & +1 & -1 & -1 & -1 & +1 & 0.97 & 4.7 \\
\hline 10 & -1 & +1 & -1 & -1 & +1 & 0.957 & 4.65 \\
\hline 11 & -1 & -1 & +1 & +1 & -1 & 1.098 & 4.27 \\
\hline 12 & +1 & +1 & +1 & +1 & -1 & 1.283 & 3.96 \\
\hline 13 & +1 & -1 & -1 & +1 & -1 & 1.071 & 4.33 \\
\hline 14 & -1 & +1 & -1 & +1 & -1 & 0.978 & 4.61 \\
\hline 15 & -1 & -1 & +1 & -1 & +1 & 1085 & 4.32 \\
\hline 16 & +1 & +1 & +1 & -1 & +1 & 1.252 & 3.85 \\
\hline
\end{tabular}

The calculation of the regression coefficients allowed to obtain the following mathematical models of the workflow of a grain crusher with a feeding device:

$$
\begin{aligned}
& y_{1}=1.06425+0.058125 x_{1}+0.015 x_{2}+0.09775 x_{3}+0.0024125 x_{4}+0.02175 x_{5}+ \\
& 0.020125 x_{1} x_{2}+0.020625 x_{1} x_{3}-0.0025 x_{1} x_{4}+0.010375 x_{1} x_{5}-0.026 x_{2} x_{3}-0.021875 x_{2} x_{4}+(1) \\
& 0.011 x_{2} x_{5}+0.011125 x_{3} x_{4}-0.00425 x_{3} x_{5}-0.047625 x_{4} x_{5} \\
& y_{2}=4.36917-0.155417 x_{1}+0.023333 x_{3}-0.265833 x_{3}-0.0620833 x_{4}+0.0408333 x_{5}- \\
& 0.0295833 x_{1} x_{2}-0.0329167 x_{1} x_{3}+0.0558333 x_{1} x_{4}+0.0179167 x_{1} x_{5}+0.0883333 x_{2} x_{3}+(2) \\
& 0.0270833 x_{2} x_{4}-0.093333 x_{2} x_{5}+0.0279167 x_{3} x_{4}+0.02834334 x_{3} x_{5}+0.0920833 x_{4} x_{5}
\end{aligned}
$$

After exclusion of the insignificant factors (according to Figs. 4-5) the following models of the grain crushing technological process were finally obtained:

$$
\begin{aligned}
& y_{1}=1.055+0.070 x_{1}+0.086 x_{3}+0.013 x_{4}+0.011 x_{1} x_{2}+0.030 x_{1} x_{2}-0.017 x_{2} x_{3}-0.013 x_{2} x_{4}- \\
& -0.039 x_{4} x_{5} \\
& y_{2}=4.353-0.129 x_{1}+0.050 x_{2}-0.292 x_{3}-0.088 x_{4}+0.067 x_{5}-0.046 x_{1} x_{2}+ \\
& 0.072 x_{1} x_{4}+0.105 x_{2} x_{3}+0.043 x_{2} x_{4}-0.110 x_{2} x_{3}+0.045 x_{3} x_{5}+0.108 x_{4} x_{5}
\end{aligned}
$$

Investigation of the dispersion homogeneity produced the Cochran's Q test values showing that the dispersions are homogeneous. Adequacy of Equations (1-4) was verified using the Fisher F-test the equations are adequate. 
The analysis of the results of the multifactor experiment indicates that the most significant factors affecting the crushing efficiency $y_{1}\left(Q, \mathrm{t} \cdot \mathrm{h}^{-1}\right)$ and its energy intensity $y_{2}\left(E, \mathrm{~kW} \cdot \mathrm{h} \cdot \mathrm{t}^{-1}\right)$ are the rotational speed of the feeding roll $x_{1}\left(\mathrm{~min}^{-1}\right)$ and the diameter of the feeding roll $x_{3}$ (m.) (Fig.4).

a)

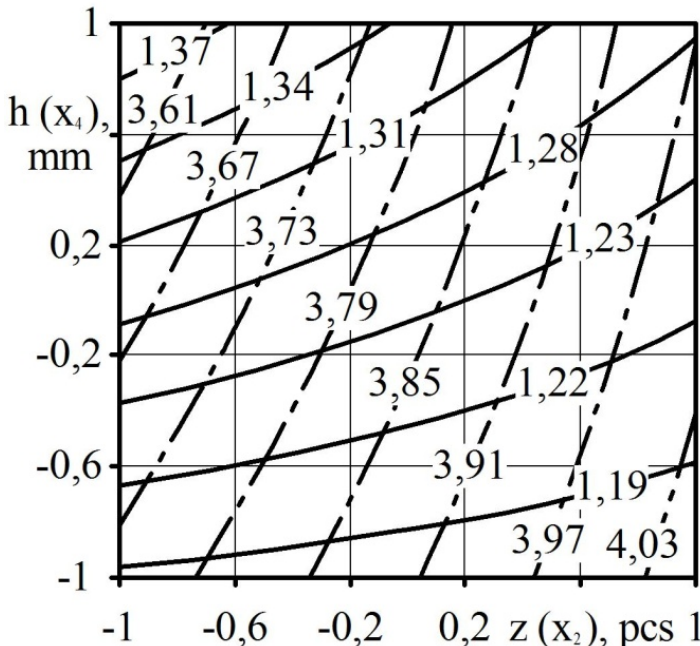

c)

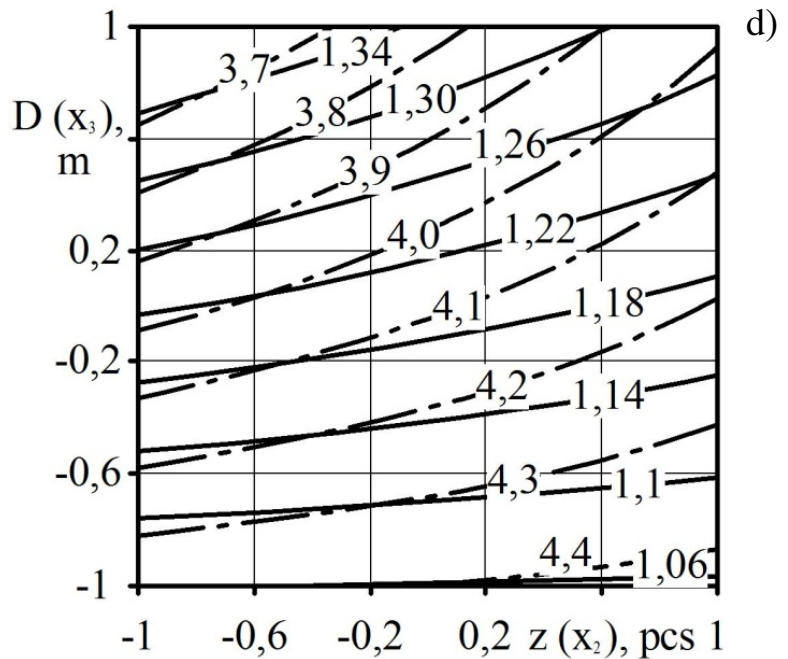

b)

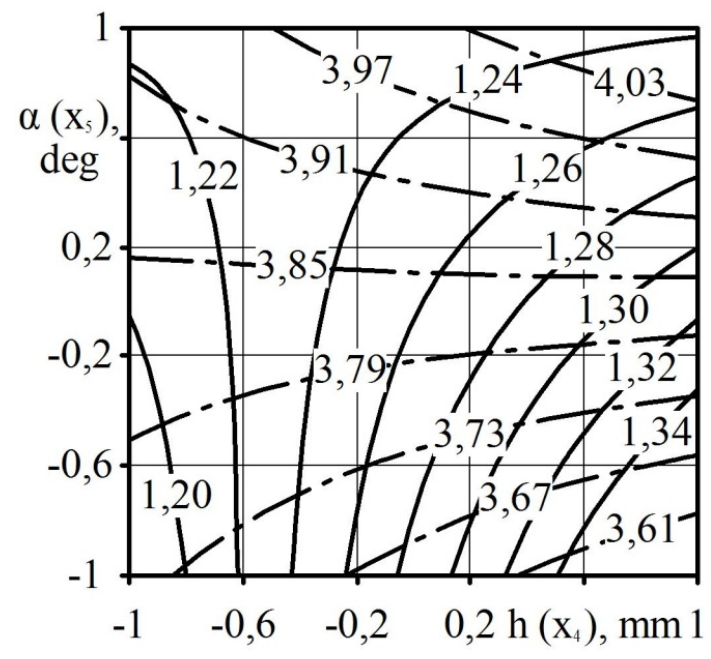

d)

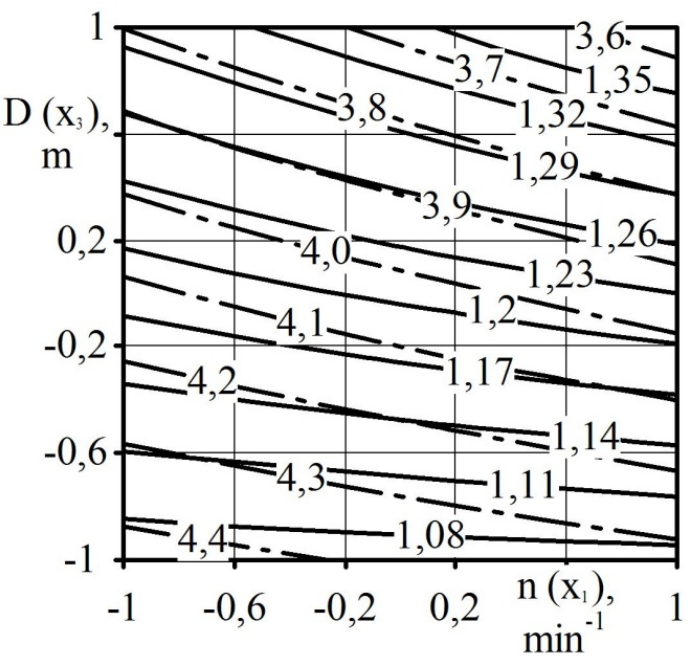

Fig. 4. Two-dimensional sections of response efficiency $Q, \mathbf{t ~ h}^{-1}(-)$ and specific energy consumption $E, \mathrm{~kW} \cdot \mathrm{h} \mathrm{t}^{-1}(---)$ at various fixed factors:
a) $-x_{1}=1\left(n=900 \min ^{-1}\right), x_{3}=1(D=0.2 \mathrm{~m}), x_{5}=-1\left(\alpha=0^{\circ}\right)$;
b) $-x_{1}=1\left(n=900 \mathrm{~min}^{-1}\right), x_{2}=-1\left(z=16 \mathrm{pcs}, x_{3}=1(D=0.2 \mathrm{~m})\right.$;
c) $-x_{1}=1\left(n=900 \mathrm{~min}^{-1}\right), x_{4}=1(h=370 \mathrm{~mm}), x_{5}=-1\left(\alpha=0^{\circ}\right)$;
d) $-x_{2}=-1(z=16 \mathrm{pcs}), x_{4}=1(h=370 \mathrm{~mm}), x_{5}=-1\left(\alpha=0^{\circ}\right)$.

As a result of the multifactor experiment $\left(2^{5-1}\right)$, the best indicators of the optimization criteria were obtained: the crushing efficiency $Q=1.34 \ldots 1.37 \mathrm{t} \cdot \mathrm{h}^{-1}$, and the specific energy consumption $E=3.6 \ldots 3.7 \mathrm{~kW} \cdot \mathrm{h} \cdot \mathrm{t}^{-1}$ at the rotation frequency of the roll of the feeding device $x_{1}=n=$ $800 \ldots 900 \mathrm{~min}^{-1}$, the number of blades of the roll $x_{2}=z=32$, the diameter of the roll of the feeding device $x_{3}=D=0.2 \mathrm{~m}=00$, the installation height of the feeding roll relative to the working area of flattening $x_{4}=h=370 \mathrm{~mm}$, the inclination angle of the blades of the roll $x_{5}=\alpha=00$. Based on this, when developing the design documentation for the feeding device, it is necessary to be guided by the above values of its structural and technological parameters.

In order to test the efficiency of the experimental research, a comparison of the performance indicators of the crusher with a feeding device (the new version) was made with a crusher without it (the basic version - a series-produced crusher PZ-1) for the same crushed grain material (from the same batch) and the same settings of the crushers themselves (the diameter of the roll for flattening $D=275 \mathrm{~mm}$, the rotation speed of the roll $600 \mathrm{~min}^{-1}$, the width of the rolls $150 \mathrm{~mm}$, the inter-roll gap $0.9 \mathrm{~mm})$. 
When flattening the same grain (barley of the Abava variety with $12 \%$ moisture) using a grain crusher with a feeding device installed on it (the new version) with the parameter values: the rotation frequency of the feeding roll device $n=850 \mathrm{~min}^{-1}$, the number of blades of the roll $z=32 \mathrm{pcs}$., the diameter of the feeding roll $D=0.2 \mathrm{~m}$, the installation height of the feeding roll relative to the working area of flattening $h=370 \mathrm{~mm}$, the inclination angle of the blades of the roll $\alpha=00$, the following indicators of the technological process were achieved: the flattening efficiency was $1.34 \ldots 1.37 \mathrm{t} \mathrm{h}^{-1}$ $\left(2.25 \ldots 2.3\right.$ times), the energy consumption of the process $3.6 \ldots 3.7 \mathrm{~kW} \cdot \mathrm{h} \cdot \mathrm{t}^{-1}(1.68 \ldots 1.73$ times $)$ at the same quality of the forage produced.

\section{Conclusions}

1. Experimental investigations of the design-and-technological parameters of the feeding device of the crusher made it possible to optimise its design parameters according to the criteria of minimum energy intensity and maximum efficiency.

2. Installation of the experimental feeding device on a series-produced crusher provides its increased efficiency in comparison with the base unit (without a feeding device) from $0.596 \mathrm{t} \cdot \mathrm{h}^{-1}$ to $1.34 \mathrm{t} \cdot \mathrm{h}^{-1}\left(2.25\right.$ times), reduced energy intensity of the flattening process from $6.225 \mathrm{~kW} \cdot \mathrm{h} \cdot \mathrm{t}^{-1}$ to $3.7 \mathrm{~kW} \cdot \mathrm{h} \cdot \mathrm{t}^{-1}(1.68$ times $)$.

\section{References}

[1] Лачуга Ю. Рекомендации по заготовке и использованию высоковлажного фуражного зерна (Recommendations for the Preparation and use of Forage Grain with High Moisture Content), Moscow, 2006, 130 p. (In Russian).

[2] Bulgakov V., Holovach I., Bandura V., Ivanovs S. A theoretical research of the grain milling technological process for roller mills with two degrees of freedom. INMATEH - Agricultural Engineering. Vol. 52(2), 2017, p. 99-106.

[3] Vaculik, P., Maloun, J., Chladek, L., Poikryl, M. Disintegration process in disc crushers. Research in Agricultural Engineering. Vol. 59, Issue 3, 2013, pp. 98-104.

[4] Smejtková A., Vaculík P. , Přikryl M. Rating of malt grist fineness with respect to the used grinding equipment. Research in Agricultural Engineering, 62(3), 2016, pp. 141-146.

[5] Русаков Р., Жвакина В., Тимкина Е., Одегов В. Влияние плющения и консервирования зерна ржи на его химический состав и питательную ценность Материалы научной сессии Кировского филиала PAE (Impact of the rye grain flattening and preservation upon its chemical composition and nutritional value, Collection "Materials of the scientific session"), Kirov, 2004, pp. 275-276. (In Russian).

[6] Sysuev, V., Ivanovs, S., Savinyh, P., Kazakov, V. Movement and transformation of grain in twostage crusher. Engineering for Rural Development, Proceedings, Vol.14, 2015, pp. 22-27.

[7] Патент RU №2513391. Машина для фракционирования и очистки от примесей зернового материала (A patent RU 251339. A machine for fractionation and cleaning of the grain material from admixtures). Авторы: Сычугов Н., Сычугов Ю., Казаков В., 2014. (In Russian).

[8] Dal-Pastro E., Facco P., Bezzo E., Zamprogna E., Barolo M. Data-driven modelling of milling and sieving operations in wheat milling process. Food and Bioproducts Processing, Vol.99, 2016, pp.99-108.

[9] Bavram M., Oner M. Bulgur milling using roller, double disc and vertical disc mills, Journal of Food Engineering, vol.79(1), 2014, pp.181-187.

[10] Rosenkranz, S., Breitung-Faes, S., Kwade, A. Experimental investigations and modelling of the ball motion in planetary ball mills. Powder Technology, 212 (1), 2011, pp. 224-230.

[11]Bulgakov V., Pascuzzi S., Ivanovs S., Kaletnik G., Yanovich V. Angular oscillation model to predict the performance of a vibratory ball mill for the fine grinding of grain. Biosystems Engineering, vol. 171, 2018, pp.155.-164.

[12] Фирсов М.М. Планирование эксперимента при создании сельскохозяйственной техники. (Planning of an experiment when creating agricultural machinery), Moscow, 1999, 129 p. (In Russian). 